\title{
高出力レーザー用補償光学系
}

\author{
植田 憲一
}

電気通信大学レーザー極限技術研究センター（䍃 182-8585 東京都調布市調布ヶ 丘 1-5-1）

\section{Adaptive Optics for High Power Lasers}

\author{
Ken-ichi UEDA \\ Institute for Laser Science, University of Electro-Communications, 1-5-1 Chofugaoka, Chofu, Tokyo 182-8585
}

(Received November 20, 1998)

\begin{abstract}
Adaptive optics systems for high power gas lasers and solid state lasers are reviewed. Large scale deformable mirrors with magnetostrict actuators were cooled by water for use with huge output infrared lasers. The simple mirrors which are deformable by the hydro pressure were applied to adaptive resonators for thermal lens compensation with solid state lasers. A silicon wafer mirror was proposed as an automatic adaptive resonator for LD-pumped YAG lasers. New techniques employing a spatial phase modulator, phase-conjugated mirrors, and hybrid laser crystals are introduced.
\end{abstract}

Key Words: Deformable mirrors, Actuator, Spatial phase modulator, Phase conjugation, Hybrid laser crystals

1.はじめに

光の波面制御を行う補償光学(以後アダプティブ光学と 記述する)の有力な応用分野の一つは大出力レーザーで あった．特に軍事研究目的に開発された巨大出力レー ザーでは, レーザー共振器用光学系やレーザービーム伝送 用の光学系にアダプティブ光学系が利用されてきた. し かし, 最近では加工用の高出力レーザーが固体化され, 熱 レンズ効果を補償するためのアダプティブレーザー共振 器など, 新しい時代のアダプティブ光学系が開発されつつ ある. 本論文では, 高出力レーザー用のアダプティブ光学 系について紹介する。

\section{2. 大出力炭酸ガスレーザー, 化学レーザー}

連続的な出力の高出力レーザーの代表的なものは, ガス ダイナミックレーザーや化学レーザーである、いずれも 発振波長が赤外域で長波長が特徴である。そのために，ま さに熱線レーザーとして開発されており, ミラー材料は金 属反射鏡である。赤外線領域では謀電体多層膜のような 高反射率ミラーはできないので, 約 $2 \%$ の吸収が存在する. しかし,もしレーザー装置の出力がメガワット級になると, $2 \%$ 吸収でも $20 \mathrm{~kW}$ 熱入力が定常的に存在することにな る。したがって, 熱的破壊も深刻であり, 同時に熱変形を 避けることができない。このため, 熱変形を補償できるア ダプティブ光学系 ${ }^{1,2)}$ は巨大出力レーザーにとって不可欠 の技術である，熱変形をできるだけ避けて, 同時に熱破壊
を防止するためには, 光学基板の材料の選定から考慮する 必要がある。これまでに用いられている材料は, $\mathrm{Cu}, \mathrm{Be}$, $\mathrm{SiC}, \mathrm{Si}, \mathrm{Mo}$ な゙である。Cuは熱伝導に優れた金属基板であ るが, 重量が重く, 研磨特性がよくない. 大型光学系では 自重による自己変形が深刻なので, 比重が小さいというの は重要な特性である。最近ではダイヤモンド研削機の性 能が向上し, 大型光学基板を直接製作することも可能であ る. Beは軽量, 熱伝導の両面から理想的な材料であるが, き わめて有毒な材料なので, 粒子飛散を防止するため研磨過 程などを完全隔離する必要があり, 米国などでは工場内に 減圧した特別の工場が造られている。

アダプティブ光学系によく用いられるハニカム構造は, 表面積を大きく拡大するので, それ自身で冷却能力が大き くなる.しかし, それだけでは不十分で, 特別の冷却機構 のついたものもある. 水冷された大口径アダプティブミ

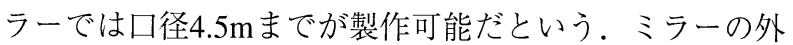
観は冷却機構や駆動機構によってさまざまだが,いずれも 薄板で作られた光学ミラーの背後に多数のアクチュエー 夕が並んでいる，ユニークな材料を紹介すると，ミラー基 板それ自体を多孔質, 発泡材料にして, それらを貫通する 水路に冷却水を流して冷却するものもある。基板そのも のに冷却機能を持たせて,それ自体を全体として変形させ ようというものである。さらに, 極端な例では, レーザー 用ミラーの背面に水滴を含む空気を衝突させて, 水滴の蒸 発熱によって冷却しようというものまである。これらは, ミラー基板そのものの温度が高温で使うことを前提とし ており, 高温に耐える材料でミラーを構成すれば, 冷却能 
率そのものは室温動作に比べて温度が高い分だけ向上さ せることができる.

赤外レーザー用の光学素子にとっての問題は, 光学素子 の熱暴走である. 半導体やイオン結晶のような光学材料 では, 素子温度が高くなると, 電子が熱励起されるので, そ れによる吸収係数の増大がある.この過程は, レーザー光 の吸収 $\rightarrow$ 温度上昇 $\rightarrow$ 電子励起 $\rightarrow$ 吸収増大 $\rightarrow$ 熱入力の増大 つさらなる温度上昇 $\rightarrow$ 吸収増大というように,レーザー光 の吸収から温度上昇の過程で正帰還がかかるので, 帰還利 得が1を超えると,熱暴走が起こってたちまち光学素子の破 壊に至る。

巨大出カレーザー用のアダプティブ光学では, 光学素子 が巨大なのでピエゾ素子以外の駆動距離が大きなアク チュエー夕も開発されている. Fig.1はその一つで, コイル 構造の磁歪型素子3)である。磁歪素子で作成したコイルに 磁界発生用のコイルを2重螺旋状に巻き付けて, 磁界強度に 比例した変位制御を行う。磁歪効果の大きな新材料 (TERFENOLD)のViederman効果を利用した平板状スプリ ング4)のアクチュエータも開発された。

大口径ミラーに扔ける問題点の一つは機械的振動に弱 く, 焦点スポットが振動することである。このようなス ポットダンスを補正するには, 駆動部の高速応答性を考慮 する必要がある. Fig.2はその結果であるが, 数 $10 \mathrm{~Hz}$ 以下の 振動は完全に補正されており, 意外とアダプティブ光学系 による制御が有効であることを示している。このことか らすると,より小さな光学系を制御すれば,アアダプティブ 光学系による描面も不可能ではないといえる。ビーム掃 引と同時に収差の自動補正が必要なので, 難しい問題があ ることは間違いないが,アダプテイブ光学系による直接描 画は将来の重要なテーマである.ささらに, 光学的防振台の 困難は低周波振動の除去にあることを考えると,防振性能 の不足を集光光学系自身で補正することは考えてよい。

アダプティブ光学系に扔ける駆動素子間の相互干渉の 影響や,アクチュエータの数や配置の最適化については, 理 論・実験両面からの研究が行われている. 薄膜の変形は

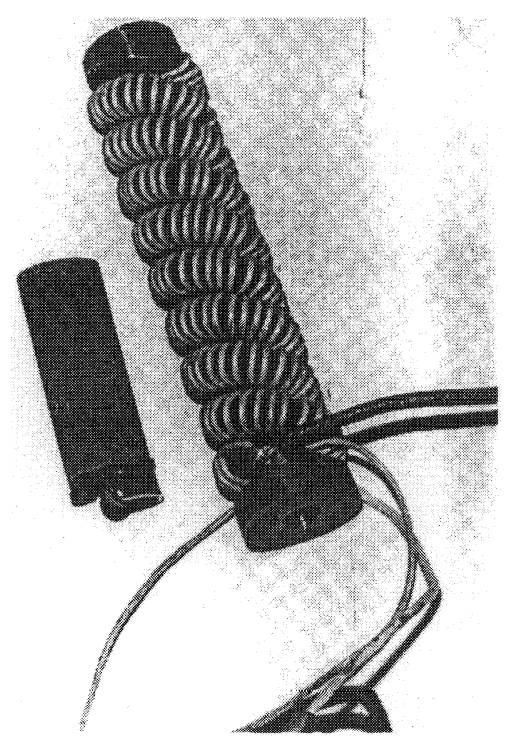

Fig.1 Magnetostrict spring-style actuator.

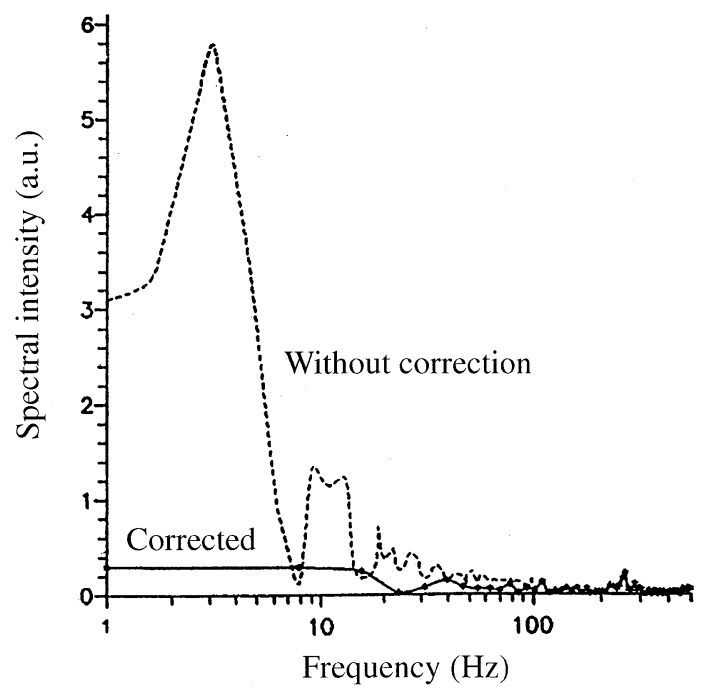

Fig.2 Vibration isolation of optical image by adaptive optics.

理論的に解明され, 理論に基づいて多数の駆動装置を制御 するための最適化アルゴリズムはよく解明されている。 効率のよいアルゴリズムの開発により,現在のパソコンレ ベルでリアルタイム制御が可能になりつつある。

\section{3. 高出力固体レーザー用アダプティブ光学系}

高出力固体レーザーは先述の気体レーザーと違って, ビーム口径が小さいのが特徴で, パワー密度が高い。さら に, 固体レーザーの特長として, 高励起入力条件では熱レ ンズが発生するので, Fig.3のように熱レンズを補償できる アダプティブ光学系が望まれる，我々は熱レンズを補正 するためのアダプティブ光学系を設計製作し, 実際にフ ラッシュランプ励起固体レーザーに適用5)した。その構造 はガラスの厚板基板を穿って, 厚さ 250 ミクロン, 口径 $9 \mathrm{~mm}$ の薄板部分を形成したものである。薄板部分の表面は光 学研磨を施し, 高反射率の誘電体多層膜をコートした。薄 板部分の背後に水を導入し, ピストンで圧力を印加するこ とで薄板ミラーを変形させる，手動のピストンで制御す るため,泡を導入して圧力緩和を行った. 圧力変形ではパ スカルの原理が成立するので, 薄板部分にかかる圧力は一 定で, 周辺の固定端の付近をのぞけば、基本的に球面的な 変形をすることが原理的に分かっている。したがって，

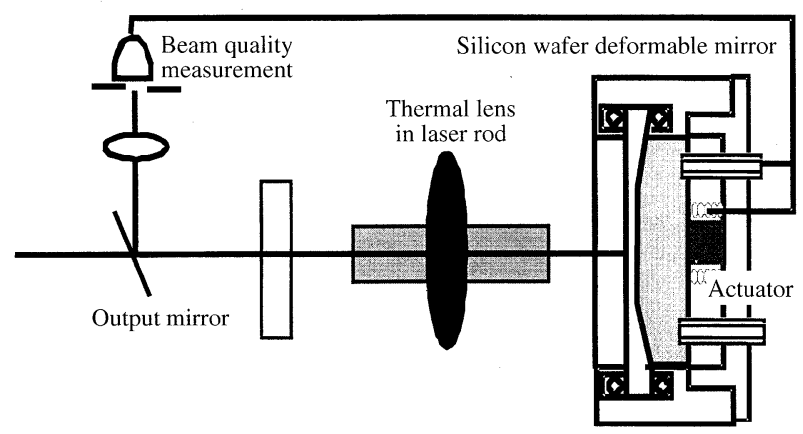

Fig.3 Cross section of deformable glass mirror with pressure control. 
ビーム径の小さな固体レーザー用の光共振器で, 熱レンズ 補正を行うためのミラーとしては十分である。50Hzの放 電駆動の小型YAGレーザー(ロッド径 $6 \mathrm{~mm}$, 長さ $60 \mathrm{~mm}$ )を 使って実験を行った。結果をFig.4に示すが, 共振器条件は a:平面共振器, b:Variable Reflectance Mirror(VRM) 共振器, c:平面ミラーとアダプティブミラー, d:VRMとアダプティ

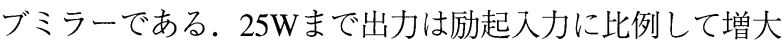
した．しかし, 集光強度でビーム品質を評価すると, 通常 の平面共振器の場合, 出力増大しても集光強度は低いレ心゙ ルで飽和してしまう。すなわち,レーザー出力が増大して も, 利用できるパワーは変化しない. 一方, アダプティブ 共振器にして, 熱レンズ効果を含めてミラー曲率を補正す ると, 出力増大はそのまま集光強度に反映し, 高出力とは 高強度を意味するという本来のレーザー高出力が実現で きる。これらの事情は, 出力ミラーに反射率分布を与えた ミラーを用いたときも同様に成立した。もちろん, 熱レン ズ効果が極端に強くなり, 共振器の安定条件を外れるよう なことがあると,レーザー出力そのものが減少することが 観測される。

高反射率ミラーにアダプティブミラーを応用する場合, ミラー基板が透明である必要はない。 そこで, シリコン ウェハーをミラー基板としたアダプティブミラーを考案 し, 試作した. Fig.5のようにシリコンウェハーの背後にシ リンダーを組み込んで, 背面板をネジで駆動するカセット 構造とした. 手動でも, モーター駆動でも, 水圧で変形さ せるミラーができる．レーザーの出力強度が最大になる ように, 自動制御をかけることも可能である. ガラスの薄 膜ミラーからシリコンウェハーに変えた場合の意味は何 だろう. 半導体製造技術の進歩は, 近い将来に半導体製造 基板の表面精度が光学面になることを予想させる．その 場合, 光学研磨の費用がほとんど不要になるという利点が ある.シリコンの熱伝導はガラスの150倍で背面水冷はよ り効果的となる.さらに,シリコン基板は精密エッチング で背面加工することが可能で, 機械定数を分布させること で熱レンズ効果の非球面項の補正も不可能ではない. 実 際, 熱レンズ補正に必要なアダプティブ光学系は, あらゆ

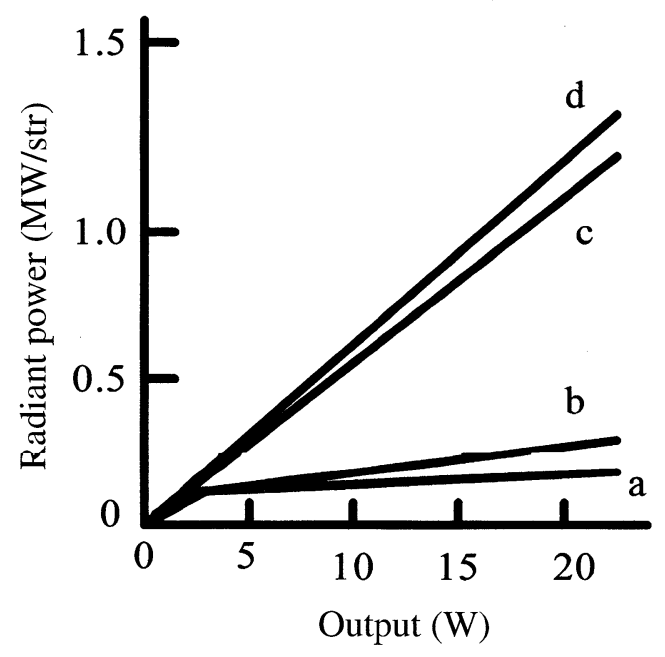

Fig.4 Beam intensity characteristics of adaptive laser resonator.

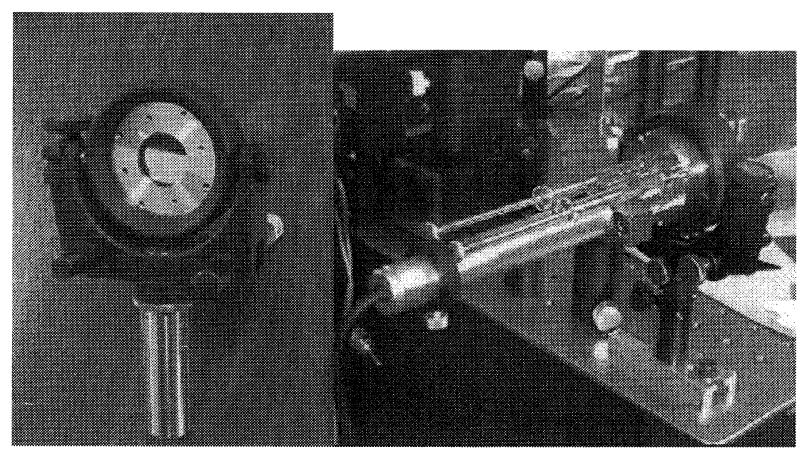

Fig.5 Si wafer deformable mirror with precision motor drive.

る条件に対応するものでなくても, 最大パワーの条件で熱 レンズを補正し, 集光強度の高い出力を発生できれば役割 を果たしたといえるので, 最適条件を絞り込んで, それに 対応した設計をしたシリコンウェハーミラーは十分な価 值を持つといえる。ささらに, モーター駆動部を外して背面 のねじで曲率を制御する曲率可変ミラーはそのままミ ラーホルダーに組み込まれ, むしろこのようなカプセルを 含んだミラーが将来のミラーのあるべき形といえるかも しれない. LD励起YAGレーザーを使って, 集光強度とミ ラー曲率の関係を求めた結果はFig.6の通りである. 最大 集光強度を与える条件から判断すると, 自動的に最適化で きるレーザー共振器を利用するには出力安定度がよい レーザーでなければ難しいことが分かる，その意味で, 共 振器の自動制御はLD励起固体レーザーに適した方式であ る.

\section{4. 超短パルスレーザー用位相補償光学 ホログラフィック光学素子と液晶空間位相変調器}

短パルスレーザーに応用すると,パルス幅の中で波面計 測し，その波面を補正することは困難である。しかし, 核 融合用レーザーのように多段の増幅システムを持つ大型 レーザーシステムでは, 多数の並列ビーム間の位相乱れを 補正したり,ショット毎の熱歪みを補正する静的なアダプ ティブ光学系に意味がある. 多段の増幅システムでは, 各 増幅器の特性の差による波面のずれが避けられない。計

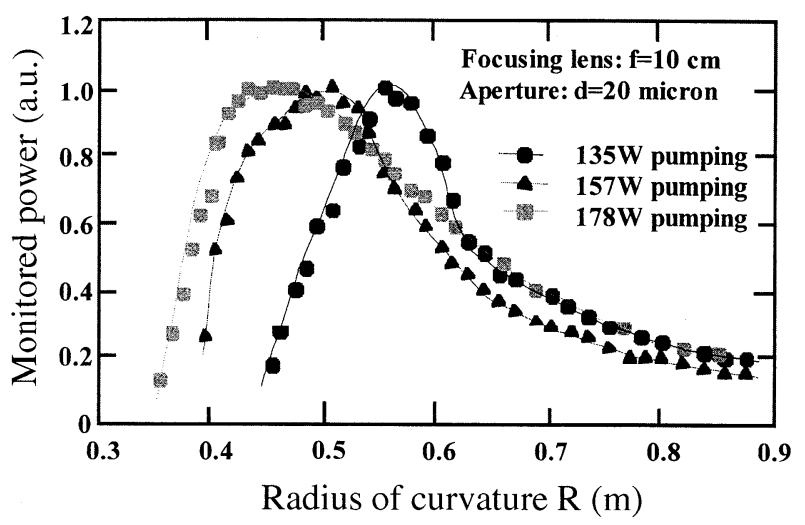

Fig.6 Focusing power vs mirror curvature of adaptive cavity. 
測された波面歪みを計算機ホログラムで補正すれば, 多数 のビームの収束点における光学強度を向上できる.

一方, ピークパワーに比較してパルスエネルギーの小さ な超短パルスレーザーでは, よりダイナミックな液晶空間 位相変調器が利用されている. 多段増幅超短パルスレー ザーシステムで, 3波シェアー干渉計で波面を計測し, 解析 結果を光伝導性のBSO結晶をコーティングした液晶空間位 相変調器に反転投影して補正すると, 直前のパルスで観測 された位相歪みを使って集光特性を改善できる，液晶は $600 \mathrm{~nm}$ より長いところでは透明である. 空間分解能は液晶

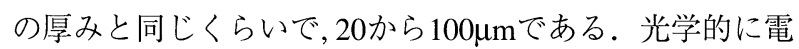
界を誘起させて, 分割電極を用いないために, 回折という 問題を生じないという利点がある。

\section{5. 位相共役光学系とビーム結合}

アダプティブ光学には変形制御光学素子による波面制 御のほかに, 非線形光学を用いたものがある．位相共役光 学系がそれで, 高強度のレーザー光を位相共役媒質, たと えば気体や液体に集光すると, 媒質中に発生する誘導ブリ ルアン散乱 (SBS)によって光の波面と結合した音波がた つ. その場合, 音波とは媒質の密度変動であるので, 光波 動と結合した屈折率分布が生じる。これは光波動が自ら 形成した周期的屈折率分布, すなわち回折格子である。自 己形成回折格子によってブレーズ反射を起こせば,つねに 入射方向に光を反射させることができる。これによって， 反射される光ビームは, 入射光に比べて伝播ベクトルだけ が反転した位相共役波となるので, 途中の経路で発生した 光学擾乱をすべて逆行補正できて, 強度だけが増大した光 を光源位置で再現できる.

典型的な位相共役光学系の応用例6)をFig.7に示すが, レーザー発振器から出た光は4本のビームに分けられた後, おのおの2パス増幅器に入射し増幅される。増幅器で1パ ス増幅後, 4本のビームは位相共役セルに入射して, SBSミ
ラーで反射された後, 2パス目の増幅をして波長変換され， 望遠鏡に入射して上空に向かって発射される。この場合, SBS媒質としては, $\mathrm{N}_{2}$ ガスが用いられたが,ガス中の微粒子 を完全に除去して, 高強度レーザー光の集光時に絶縁破壊 を起こさないようにした，同様の処理は液体媒体の場合 にも行われ, 高い反射率を示すSBS媒体, フロリナートでも 微粒子除去は特性改善に重要な役割を果たした。ガラス ファイバ7)がSBS位相共役鏡として利用できることが実証 され，簡便で安定な位相共役光学系として期待されてい る. 位相共役光学系を利用すると, 多束のファイバレー ザーなどで発振した多数のレーザービームを結合するこ とが原理的に可能になると期待される。しかし, ファイバ 内に扮ける偏光回転などの影響を考えると, 通常の位相共 役光学系では, それはスカラー位相共役なので, 偏光まで 含む位相共役波を発生することはできない。ただし，より 複雑ではあるが, 4光波混合型のベクトル位相共役ミラー8) によってビーム結合を行うことも可能になりつつある.

$$
\text { 6. ハイブリッドレーザー結晶 }
$$

ハイブリッドレーザー結晶9)の考え方は, 一面でアダプ ティブ光学の対局にあるが, 他方では物質そのものの中に アダプティブな特性を内包すると考えることができる. たとえば, $\mathrm{Nd}^{3+}: \mathrm{YVO}_{4} / \mathrm{SVAP}$ ハイブリッドレーザーは, 熱レ ンズ効果 $\mathrm{d} n / \mathrm{d} T>0$ と $\mathrm{d} n / \mathrm{d} T<0$ の結晶を組み合わせ, レー ザー媒質全体としての熱レンズ効果を補償するものであ る.2つのレーザー媒質の熱レンズ効果, 熱伝導係数, 吸収 係数をTable 1に示した. LD励起の場合, 端面励起によって 吸収される励起パワーは正確に計算できるので,

$$
\frac{1}{f}=\frac{P_{h} \mathrm{~d} n / \mathrm{d} T[1-\exp (-\alpha L)]}{\pi K_{c} \omega_{p}^{2}}
$$

の関係を使って, 吸収係数 $\alpha$, 熱伝導係数 $K_{c}$, ビーム半径 $\omega_{p}$, 励起熱入力 $P_{h}$, 屈折率の温度依存性 $\mathrm{d} n / \mathrm{d} T$ から求めることが

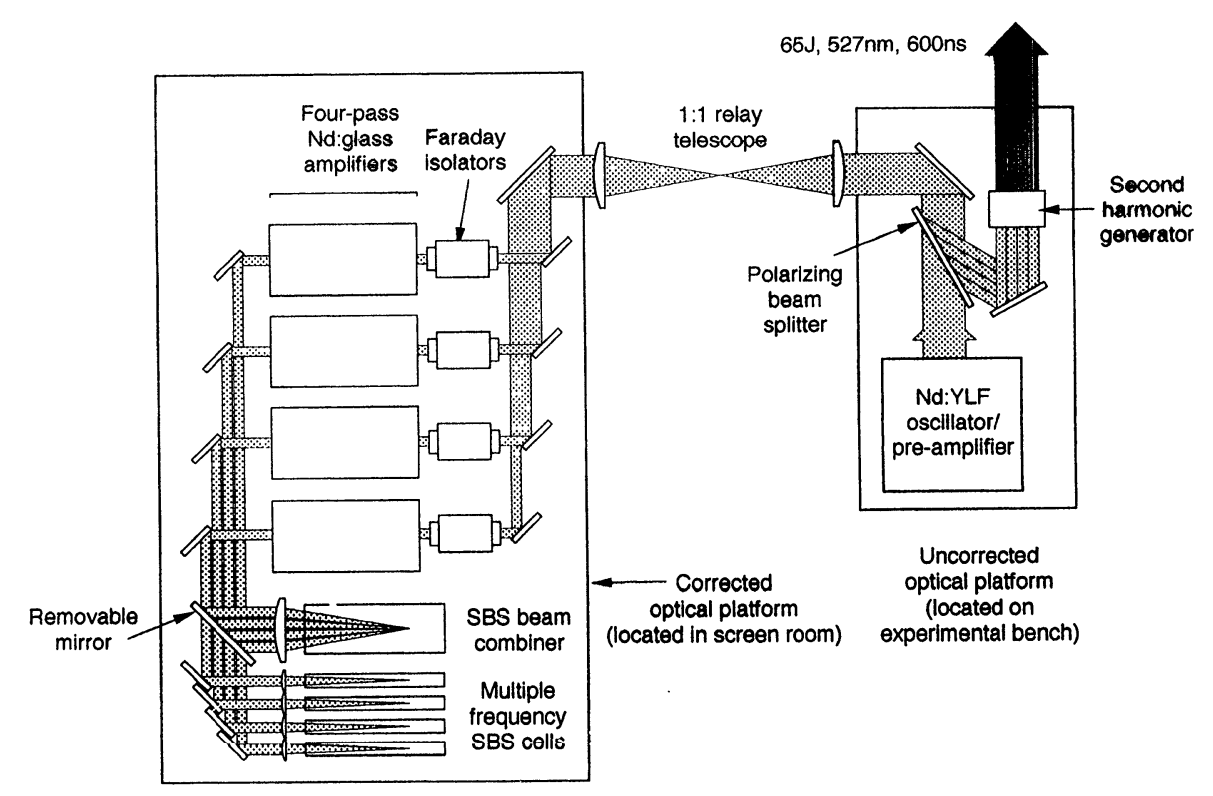

Fig.7 Multi-amplifier laser illuminator with SBS beam combining mirror. 
Table 1 Constants related to the thermal lensing effects of hybrid crystals.

\begin{tabular}{cccc}
\hline \hline & $\mathrm{d} n / \mathrm{d} T\left(\times 10^{-6} /{ }^{\circ} \mathrm{C}\right)$ & $K_{c}(\mathrm{~W} / \mathrm{m} . \mathrm{K})$ & $\alpha\left(\mathrm{cm}^{-1}\right)$ \\
\hline $\mathrm{Nd}: \mathrm{SVAP}$ & -8 & 1.7 & $5(1 \mathrm{wt} . \%)$ \\
$\mathrm{Nd}: \mathrm{YVO}_{4}$ & +8.5 & 5.1 & 33.6 \\
\hline \hline
\end{tabular}

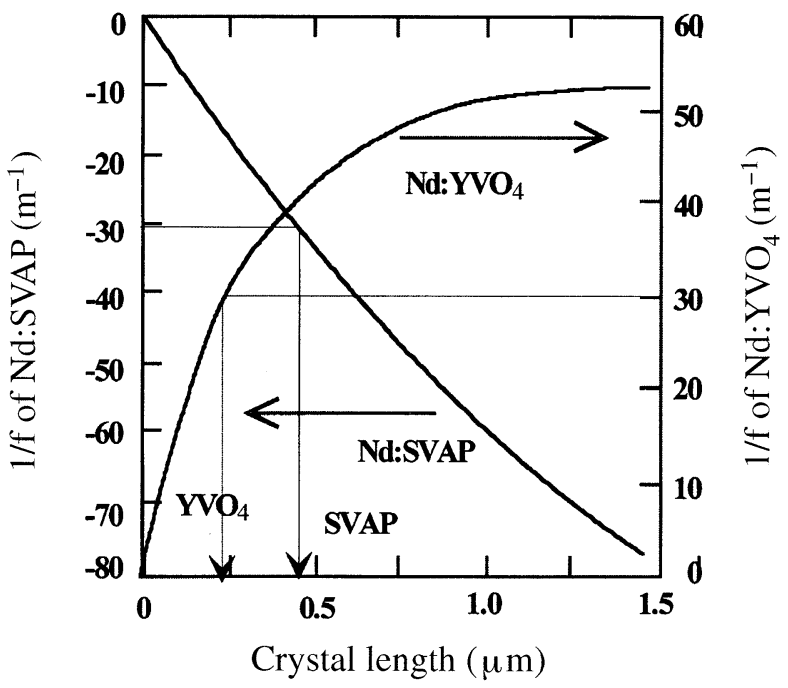

Fig.8 Nd:SVAP/YVO 4 hybrid laser crystals for thermal lens compensation.

できる，熱レンズ効果補償から計算すると,Fig.8のように $\mathrm{SVAP}$ とVO${ }_{4}$ の熱レンズ効果は $1: 2$ の割合である。端面励 起による球種効果を計算して, 厚さ $0.8 \mathrm{~mm}(\mathrm{Nd}: \mathrm{SVAP})$ と $1 \mathrm{~mm}\left(\mathrm{Nd}: \mathrm{YVO}_{4}\right)$ の結晶を用いて実験を行ったところ, 発振 波長のわずかに異なるこれら2種類の結晶は, 光学的に結合 した状態で単一のレーザー媒体として発振した。その時 のスロープ効率は54\%であった。これは単独のレーザー結 晶の発振と同等である. 励起半導体レーザーの波長を变 化させて両者の吸収量を変化させてビーム広がり角の変 化を測定したところ, 熱レンズ効果が補償された条件で もっとも小さなビーム広がり角が測定された。このよう
に,光学的に結合したハイブリッドレーザーは熱レンズ効 果を補償しつつ, レーザー媒体からのエネルギー引き出し は有効に行うことを実証した。

\section{7. まとめ}

レーザーはコヒーレント光源であり,波面の揃ったレー ザー光を発生する.したがって,レーザー光の機能を最大 限に利用するには, 波面を正確に制御できるアダプティブ 光学系が不可欠である. 当初, 軍事や天文学という特殊な 分野で発達したアダプティブ光学技術も, 波面観測技術, ア クチュエータ, 制御回路, そして計算機の発展によって, よ り一般的なレーザー技術として利用可能になりつつあ る.それと同時に, 波面制御, すなわち光の空間周波数の 制御はそれまで考えてきたよりもはるかに難しい技術課 題であり,我々は本当には3次元空間波動を制御することは まだ不十分だということも教えてくれる．21世紀はレー ザーを本当に利用する時代になるが, 光源であるレーザー とアダプティブ光学技術は, 不可久のパートナーとして発 展させられる時代になると期待している。

\section{参考論文}

1) V. V. Apollonov, V. I. Borodin, S. A. Brynkskikh, S. A. Chetkin, S. V. Muravèv, and S. N. Temnov: Exp. Tech. Phys. 37 (1989) 41.

2) G. V. Vdovin and S. A. Chetkin: Sov. J. Quantum, Electron. 20 (1993) 167.

3) V. I. Aksinin, S. A. Chetkin, V. V. Kijko, and S. V. Muravèv: Opt. Eng. 32 (1993) 447.

4) S. Chetkin and K. Ueda: Proc. Actuator 94, June 15-17, 1994, Bremen, Germany, p.29.

5) S. Chetkin and K. Ueda: 電気学会光・量子デバイス研究会資 料 OQD-94-6 (1994) 39.

6) B. Dane, K. Zepata, and L. Hackel: J. Quantum Electron. 31 (1995) 148.

7) H. Eichler, J. Kunde, and B. Liu: Opt. Lett. 22 (1997) 495.

8) M. Bowers, R. Boyd, and A. Hankla: Opt. Lett. 22 (1997) 360.

9) D. Shen, A. Liu, J. Song, and K. Ueda: OSA Annual Meeting, ThH4, Baltimore, Oct. 8, 1998.

$$
\text { レーザーワード }
$$

deformable mirrors

変形可能な反射鏡一般を指す。薄板またはメンブラン (薄膜) 状のミラーに外部から力を加えて必要な表面形状を 作り出す。変形させるための方法には, ピエゾ素子, 静電 力応用, 磁歪素子, 圧力制御など, ミラーサイズ, 試用環境,
応答時間などによって様々な方法が用いられる，波面計 測と連動して, 連続的に波面制御ができる場合はアダプ ティブ光学として知られている.

(植田 憲一)

\section{誘導ブリルアン散乱 (SBS: Stimulated Brillouin Scatter)} レーザー光のように強い電磁波を媒質中へ入射すると， 入射光によって散乱光および自然に存在する音波のうち, 位相整合条件 (運動量保存)を满たすモードが励起され, 散 乱光が増幅されて振動分極が発生する. 結果として後方 散乱光が強く励起される。これがSBSである。この媒質中 に発生する密度分布は, 音波の波長を周期とする規則的な 粗密波であり, 入射レーザー光に対して回折格子(ブラッグ
反射体)として作用する。非線形媒質中で発生した過渡的 回折格子のパターンは, 入射光の時々刻々変化する波面と 同じパターンを生成することから, 入射光と反射光の波面 は共役関係となり，位相共役光が実現される．90\%近い反 射光はエネルギー保存則から音波周波数だけダウンシフ トした周波数を持つが高出力レーザー用の位相共役鏡の 代表例である.

(吉田 英次) 